\title{
GGE Biplot Analysis of Sugar Beet Multi-Environment Trials
}

\author{
Živko Ćurčić* · Dario Danojević · Bojan Mitrović · Mihajlo Ćirić . \\ Ksenija Taški-Ajduković · Nevena Nagl
}

Institute of Field and Vegetable Crops, Maksima Gorkog 30, 21000 Novi Sad, Serbia

\begin{abstract}
Summary: Multi-environment trials are performed every year with the aim of evaluating sugar beet varieties in different environmental conditions of Serbia. The objective of this research was to interpret the effects of genotype, environment and genotype $\times$ environment interaction on root yield, sugar content and white sugar yield. GGE biplot method was used to estimate stability of seven sugar beet hybrids developed at the Institute of Field and Vegetable Crops, Novi Sad, Serbia. Mixed model of analysis of variance (ANOVA) was used for the analysis of trial results. Factor genotype effect was assumed fixed while effects of year and environment were assumed random. ANOVA showed that the environment had the greatest effect on root and white sugar yield, while year had the strongest effect on sugar content. Variations of all traits were under significant impact of genotype, while the GEI influence was not a significant. Results of GGE biplot analysis suggested that hybrid Sara was the most stable variety for root yield, while Lara had the greatest stability for sugar content and white sugar yield among the tested genotypes. Also, optimal locations were identified for each genotype, which can be useful when recommending sugar beet varieties for certain growing areas of this field crop.

Keywords: GGE biplot analysis, multi-environment trials, root yield, sugar beet, sugar content, white sugar yield
\end{abstract}

\section{Introduction}

The main goal of growing almost every agricultural crop is achieving high and stable yields, in regard to maximum utilization of environmental conditions. In addition to the applied cultivation practices, important part of this process is the selection of the most suitable variety. Beside hereditary and environmental factors, productivity of varieties is also influenced by their interaction (Kaya et al., 2006; Yan et al., 2007; Sayar et al., 2013; Djuric et al., 2016). The genotype by environment interaction (GEI) may be reduced by (i) using specific cultivars for each environment, (ii) using cultivars with wide adaptability and good stability, or (iii) by stratifying the region under study in megaenvironments with similar environmental characteristics (Oliveira et al., 2010).

Many statistical methods have been developed for quantification of interaction between genotype and environment (Crossa, 1990), but there have not been many studies on the genetic and physiological aspects of GEI . In the case of sugar beet, the evaluation of GEI

Corresponding author:

zivko.curcic@ifvcns.ns.ac.rs

Acknowledgements:

This study was funded by the Ministry of Education, Science and Technological Development of the Republic of Serbia, under the project TR31015. would be very helpful in identification of traits contributing to a better variety performance in certain environments (Hoffman et al., 2009).

One of the methods of multivariate statistics, which is often used for analysis of GEI is AMMI (Additive Main Effects and Multiplicative Interactions) (Gauch and Zobel, 1996). AMMI combines analysis of variance for explaining the main effects of genotype and environment, and principal component analysis (PCA) for explanation of interaction (GEI). The results of AMMI analysis are interpreted by using biplot.

Visual method GGE biplot (Genotype and Genotype-Environment Interaction) represents modification of AMMI model and gives extensive explanation of GEI effect (Yan et al., 2000). The method is used for visual analysis of multi-environment trials data and it is based on two concepts: biplot concept (Gabriel, 1971) and GGE concept (Yan et al., 2000). This method uses biplot for description of two factors, genotype and interaction between genotype and environment ( $G$ and GEI), which can be very useful in evaluation of performance of genotypes in different agro-ecological conditions.

Final objectives of this study were: (1) interpretation of effects of genotype, environment and GEI for root yield, sugar content and white sugar yield, and (2) stability evaluation of seven sugar beet hybrids using GGE biplot method, in regions of Serbia where this crop is grown. 


\section{Material and Methods}

The study included seven sugar beet varieties and seven locations in major sugar beet growing areas of Serbia during the period of two years (2009, 2010). All examined genotypes (Sara, Lara, Drena, Darija, Irina, Nora, and Vera) were developed at the Institute of Field and Vegetable Crops, Novi Sad, Serbia. Sara is N - type sugar beet variety with high genetic potential for root yield and sugar content. It reaches technological maturity in 160-180 days. Lara is Z - type variety and reaches technological maturity in 150-160 days. It has high sugar content and good technological quality. Drena is NE- type of sugar beet and achieves technological maturity in 160-180 days. Darija is E type hybrid and reaches technological maturity in 180200 days (Kovačev et al., 2005). Hybrid variety Irina is also E- type hybrid (Kovačev et al., 2007). Variety Nora has good balance between root yield and sugar content and belongs to $\mathrm{N}$ - type of hybrids. Variety Vera is Ztype of sugar beet (Kovačev et al., 2011). All hybrids originate from the same breeding program sharing at least $33 \%$ of germplasm because one of their components in production is the same $\mathrm{cms}$ line. All varieties are resistant to rhizomania.

During the period of two years the field trials were set according to randomized block design in five replications at seven locations: Novi Sad (NS), Vrbas (VS), Sombor (SO), Kikinda (KI), Zrenjanin (ZR), Pančevo (PA), and Sremska Mitrovica (SM). Information about trial sites is given in Table 1. Sowing was performed in optimal time in late of March. Each plot consisted of 4 rows $10 \mathrm{~m}$ length, with a row spacing of $0.5 \mathrm{~m}$ and distance between plants $0.2 \mathrm{~m}$, with the size of $20 \mathrm{~m}^{2}$. Crops were harvested manually in early October each year. During the growing period usualy agricultural practices for sugar beet were applied. The fields where the trail was established had chernozem soil type.
Sugar content and impurities were determined at the Laboratory for root quality testing of Institute of Field and Vegetable Crops, according to the standard methodology. The data were used to calculate white sugar yield with the method of Reinefeld et al. (1974):

MS $=0.343 *(\mathrm{~K}+\mathrm{Na})+0.094 *$ amino- $\mathrm{N}-0.29$.

[K, $\mathrm{Na}$ and amino- $\mathrm{N}$ in meq $\left(100 \mathrm{~g}^{-1}\right.$ beet $\left.)\right]$

$\mathrm{WSC}=\mathrm{SC}-\mathrm{MS}-\mathrm{SFL}$

SFL (standard factory loss) $=0.6$

WSY $=$ RY $*$ WSC

MS - lost to molasses, WSC - white sugar content, SC - sugar content, WSY - white sugar yield, RY - root yield

ANOVA mixed model was used to interpret the results. Factor genotype was assumed fixed and effects of year and environment were assumed random. Main effects of year $(Y)$ and environment (E) were tested against $\mathrm{Y} \times \mathrm{E}$ interaction and the $\mathrm{Y} \times \mathrm{E}$ interaction was tested against the replication within the environment $($ Rep $/(Y \times E)$ term. The $G \times Y$ and $G \times E$ interaction were tested against $G \times Y \times E$ interaction, and $G \times Y \times E$ interaction was tested against the residual. Approximate procedure by Satterthwaite (1946) was used for genotype main effect where $(\mathrm{G}+\mathrm{G} \times \mathrm{Y} \times \mathrm{E})$ were tested against $(\mathrm{G} \times \mathrm{Y}+\mathrm{G} \times \mathrm{E})$. Degrees of freedom r1 and $\mathrm{r} 2$ were calculated using the following formulas:

$$
\begin{aligned}
& \mathrm{r} 1=\frac{\left\{\left(S S_{G} /(g-1)+S S_{G Y E} /[(g-1) *(y-1) *(e-1)]\right\}^{2}\right.}{\frac{\left[S S_{G} /(g-1)\right]^{2}}{(g-1)}+\frac{\left\{S S_{G Y E} /[(g-1) *(y-1) *(e-1)]\right\}^{2}}{(g-1) *(y-1) *(e-1)}} \\
& \mathrm{r} 2=\frac{\frac{\left\{S S_{G Y} /(g-1) *(y-1)+S S_{G E} /(g-1) *(e-1)\right\}^{2}}{\left\{S S_{G Y} /(g-1) *(y-1)\right\}^{2}}}{(g-1) *(y-1)}+\frac{\left\{S S_{G E} /(g-1) *(e-1)\right\}^{2}}{(g-1) *(e-1)}
\end{aligned}
$$

R software (R Development Team, 2013) was used for the GGE biplot analysis and graphical presentation of trial data. GGE biplots representing mean vs. stability were constructed with genotype focus scaling.

\begin{tabular}{|c|c|c|c|c|c|}
\hline \multirow{2}{*}{ Trial site } & \multicolumn{2}{|c|}{ Geographic position } & \multirow{2}{*}{ Altitude $(\mathrm{m})$} & \multicolumn{2}{|c|}{$\begin{array}{c}\text { Rainfall (mm) } \\
\text { April - September }\end{array}$} \\
\hline & Latitude & Longitude & & 2009 & 2010 \\
\hline Novi Sad & $45^{\circ} 20^{\prime}$ & $19^{\circ} 51^{\prime}$ & 82 & 271.5 & 684.4 \\
\hline Vrbas & $45^{\circ} 34^{\prime}$ & $19^{\circ} 38^{\prime}$ & 79 & 324.0 & 480.7 \\
\hline Sombor & $45^{\circ} 46^{\prime}$ & $19^{\circ} 06^{\prime}$ & 87 & 258.0 & 694.2 \\
\hline Kikinda & $45^{\circ} 49^{\prime}$ & $20^{\circ} 27^{\prime}$ & 82 & 269.1 & 669.4 \\
\hline Zrenjanin & $45^{\circ} 22^{\prime}$ & $20^{\circ} 23^{\prime}$ & 80 & 288.4 & 625.3 \\
\hline Pančevo & $44^{\circ} 52^{\prime}$ & $20^{\circ} 39^{\prime}$ & 82 & 359.5 & 429.8 \\
\hline Sr Mitrovica & $44^{\circ} 58^{\prime}$ & $19^{\circ} 36^{\prime}$ & 100 & 194.5 & 509.5 \\
\hline
\end{tabular}

Table 1. Information about trial sites 
Also, the graphical view of "which won where" was presented with symmetrical scaling.

\section{Results and Discussion}

Yield and quality of sugar beet root extremely varied due to the specific weather conditions during the trails period, such as severe drought in the first year of trial (2009) and heavy rainfall in the second year (2010). In 2009 all varieties had lower root yield, higher sugar content and higher white sugar yield than in the second year. All examined hybrids achieved higher root yields (10 t/ha in average during 2010) but regardless to higher root yield compared to 2009 , all sugar beet varieties had lower white sugar yield in 2010 for $0.8 \mathrm{t} /$ ha on average, comparing to 2009 (Table 2).

Even in such small region as Northern Serbia (Vojvodina), yield and quality of sugar beet considerably differed in the different environments (Table 3). The highest root yield in both years was recorded at the site VS $80.77 \mathrm{t} / \mathrm{ha}$ in 2009; $96.51 \mathrm{t} / \mathrm{ha}$ in 2010. Sugar content varied from $13.98 \%$ in 2010 to $18.67 \%$ in 2009 at the same trial site PA. The highest white sugar yield in 2009 was recorded in VS $12.1 \mathrm{t} / \mathrm{ha}$, while in 2010 it was at trial site ZR, $12.01 \mathrm{t} / \mathrm{ha}$.

Results of ANOVA for three-factorial trial showed that effect of interaction between year and environment was significant at $\mathrm{P}<0.001$ level for all traits (Table 4).
Effect of year was significant at $\mathrm{P}<0.001$ level for sugar content and root yield because of specific weather conditions during two years of study, deficiency of precipitation in 2009 and surplus of precipitation in 2010. Year effect had no influence on white sugar yield. Environment effect was significant at $\mathrm{P}<0.05$ only for root yield. Genotype effect was significant for all investigated traits, but for sugar content it was on $\mathrm{P}<$ 0.001 level, while for root yield and white sugar yield it was on $P<0.05$. Interactions $G \times Y$ and $G \times Y \times E$ were significant at $\mathrm{P}<0.05$ level only for root yield. According to Bloch and Hoffmann (2005), Laidig claims that values of all interactions between genotype and environment in sugar beet are exceptionally low comparing to other field crops such as corn (Mitrovic et al., 2012) and wheat (Mladenov et al., 2012). The main reason for low level of interaction in sugar beet is that production of this crop is based on root and its quantitative traits which are estimated. Root grows during the vegetative phase of sugar beet development, and in contrast to other field crops does not pass through sensitive stages like bolting, flowering, pollination and seed filling (Hoffmann et al., 2009).

Although the presence of low level GEI was detected in study of Hoffmann et al. (2009) the complete explanation on genotype $\times$ environment interaction could not be offered. Cačić et al. (2005) also found the existence of GEI in Serbian environmental

Table 2. Mean values of root yield, sugar content and white sugar yield by genotype in two years

\begin{tabular}{|c|c|c|c|c|c|c|c|}
\hline \multirow{2}{*}{ Variety } & & \multicolumn{2}{|c|}{ Root yield (t/ha) } & \multicolumn{2}{|c|}{ Sugar content $(\%)$} & \multicolumn{2}{|c|}{ White sugar yield (t/ha) } \\
\hline & & 2009 & 2010 & 2009 & 2010 & 2009 & 2010 \\
\hline Sara & & 68.65 & 77.26 & 17.80 & 14.64 & 10.50 & 9.59 \\
\hline Lara & & 69.75 & 77.19 & 18.06 & 14.84 & 10.90 & 9.67 \\
\hline Drena & & 69.09 & 80.57 & 17.74 & 14.39 & 10.53 & 9.71 \\
\hline Darija & & 64.48 & 74.07 & 18.17 & 14.81 & 10.12 & 9.29 \\
\hline Irina & & 68.28 & 77.84 & 17.46 & 14.43 & 10.15 & 9.42 \\
\hline Nora & & 67.46 & 77.79 & 17.66 & 14.53 & 10.17 & 9.51 \\
\hline Vera & & 65.16 & 79.75 & 18.22 & 14.91 & 10.27 & 9.94 \\
\hline Average & & 67.56 & 77.78 & 17.87 & 14.65 & 10.38 & 9.59 \\
\hline \multirow{2}{*}{ LSD } & 0.05 & 1.97 & 3.21 & 0.32 & 0.19 & 0.37 & 0.42 \\
\hline & 0.01 & 2.59 & 4.23 & 0.42 & 0.25 & 0.49 & 0.56 \\
\hline
\end{tabular}

Table 3. Mean values of root yield, sugar content and white sugar yield on different trial sites in two years

\begin{tabular}{|c|c|c|c|c|c|c|c|}
\hline \multirow{2}{*}{\multicolumn{2}{|c|}{ Trial site }} & \multicolumn{2}{|c|}{ Root yield (t/ha) } & \multicolumn{2}{|c|}{ Sugar content $(\%)$} & \multicolumn{2}{|c|}{ White sugar yield $(\mathrm{t} / \mathrm{ha})$} \\
\hline & & 2009 & 2010 & 2009 & 2010 & 2009 & 2010 \\
\hline \multicolumn{2}{|c|}{ Novi Sad } & 78.46 & 79.68 & 17.46 & 14.00 & 12.09 & 9.58 \\
\hline \multicolumn{2}{|c|}{ Vrbas } & 80.77 & 96.51 & 17.30 & 14.44 & 12.10 & 11.64 \\
\hline \multicolumn{2}{|c|}{ Sombor } & 63.10 & 69.58 & 18.27 & 14.42 & 10.41 & 8.35 \\
\hline \multicolumn{2}{|c|}{ Kikinda } & 62.54 & 69.40 & 18.23 & 14.76 & 9.67 & 8.36 \\
\hline \multicolumn{2}{|c|}{ Zrenjanin } & 72.88 & 87.42 & 17.67 & 16.15 & 10.49 & 12.01 \\
\hline \multicolumn{2}{|c|}{ Pančevo } & 47.72 & 69.59 & 18.67 & 13.98 & 7.78 & 8.09 \\
\hline \multicolumn{2}{|c|}{ Sr Mitrovica } & 67.40 & 72.29 & 17.52 & 14.80 & 10.10 & 9.08 \\
\hline & 0.05 & 1.97 & 3.00 & 0.32 & 0.18 & 0.37 & 0.40 \\
\hline & 0.01 & 2.59 & 3.96 & 0.42 & 0.23 & 0.49 & 0.52 \\
\hline
\end{tabular}


Table 4. Combined analysis of variance for root yield, sugar content and white sugar yield over the 2009 and 2010 growing seasons

\begin{tabular}{|c|c|c|c|c|c|c|c|c|c|c|}
\hline \multirow{2}{*}{$\begin{array}{l}\text { Source of } \\
\text { variation }\end{array}$} & \multirow{2}{*}{$\mathrm{DF}$} & \multicolumn{3}{|c|}{ Root yield } & \multicolumn{3}{|c|}{ Sugar content } & \multicolumn{3}{|c|}{ White sugar yield } \\
\hline & & SS & $\mathrm{F}$ & $\%$ of total & SS & F & $\%$ of total & SS & $\mathrm{F}$ & $\%$ of total \\
\hline Year $(Y)$ & 1 & 12816 & $13.75^{* *}$ & 16.34 & 1274.3 & $73.33^{* * *}$ & 79.06 & 76.1 & 2.26 & 5.33 \\
\hline Environment (E) & 6 & 44895 & $8.03^{*}$ & 57.25 & 65.2 & 0.63 & 4.05 & 809.2 & 4.01 & 56.66 \\
\hline$Y \times E$ & 6 & 5592 & $14.74^{* * *}$ & 7.13 & 104.3 & $28.76^{* * *}$ & 6.47 & 201.7 & $21.04^{* * *}$ & 14.13 \\
\hline $\operatorname{Rep} /(Y \times E)$ & 56 & 3540 & & & 33.8 & & & 89.5 & & \\
\hline Genotype (G) & 6 & 1200 & $1.89 *$ & 1.53 & 24.5 & $7.24^{* * *}$ & 1.52 & 18.5 & $1.90^{*}$ & 1.29 \\
\hline$G \times Y$ & 6 & 557 & $2.62^{*}$ & 0.71 & 1.7 & 1.40 & 0.10 & 7.6 & 2.04 & 0.54 \\
\hline$G \times E$ & 36 & 1154 & 0.91 & 1.47 & 11.3 & 1.56 & 0.70 & 24.4 & 1.09 & 1.71 \\
\hline$G \times Y \times E$ & 36 & 1273 & $1.61^{*}$ & 1.62 & 7.2 & 0.75 & 0.45 & 22.5 & 1.17 & 1.57 \\
\hline Error & 336 & 7388 & & & 89.6 & & & 178.6 & & \\
\hline Total & 489 & 78415 & & & 1612.0 & & & 1428.1 & & \\
\hline
\end{tabular}

$*, * *, * * *$ significant at $0.05,0.01$ and 0.001 levels of probability
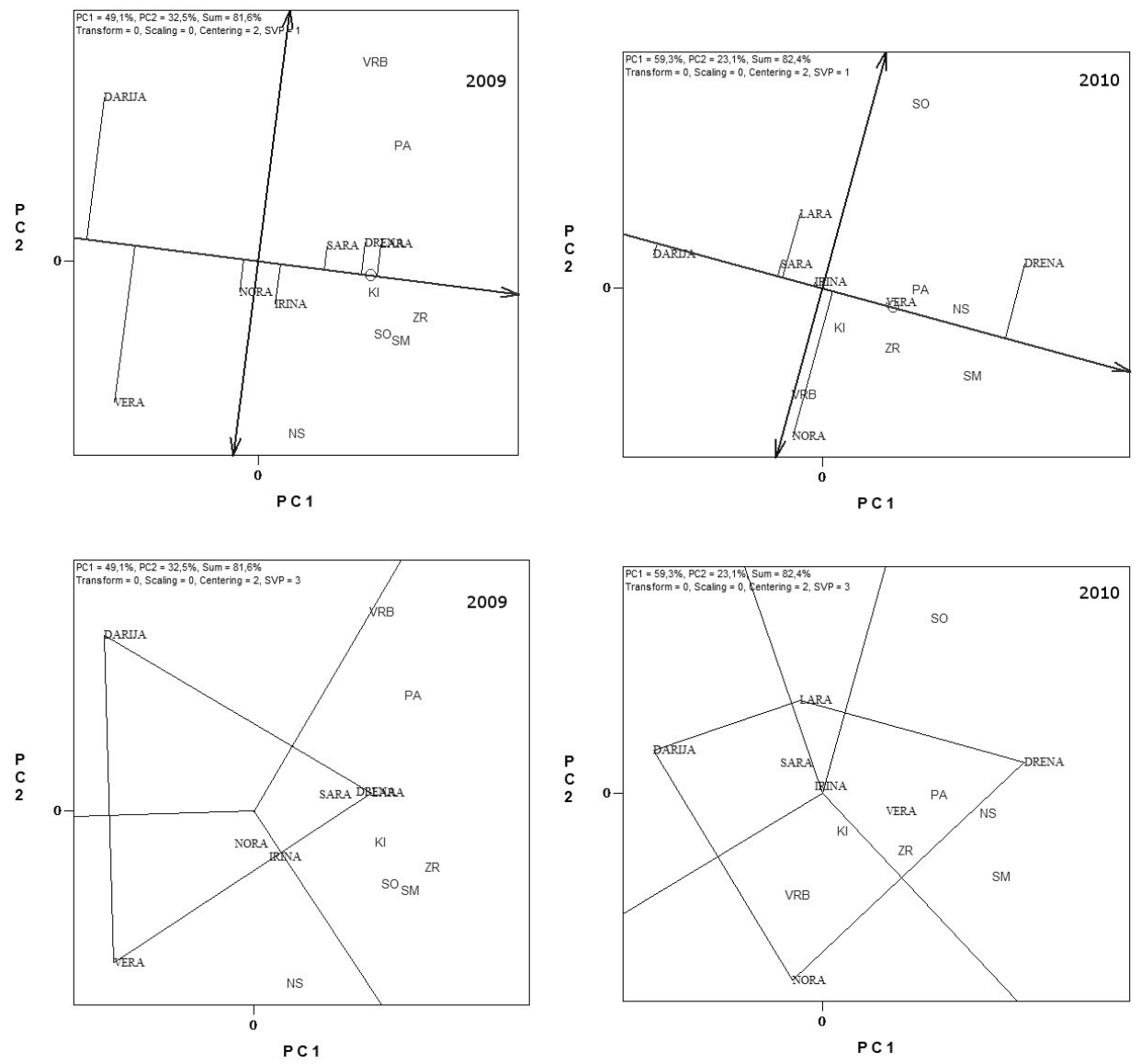

Figure 1. Mean stability and mega-environments for root yield in 2009 and 2010

conditions. Contrary to these, the results of our study showed that there was no GEI effect, despite differences between genotypes determined by ANOVA. Number of tested varieties in our investigation was the same as in research of Čačić et al. (2005), but varieties differed. Our study includes varieties from same breeding program, while Čačić et al. (2005) in their research examined genotypes from three breeding companies. The reason for the lack of significant GEI effect in this study was the origin of all tested varieties, 
which is in accordance with the conclusions Ahmadi et al. (2011), who interpreted the lack of interaction with the fact that all genotypes originated from the same population.

The first two principal components (PCA1 and PCA2) of the GGE biplot method, derived by singular value decomposition of the effects of genotype $(\mathrm{G})+$ interaction $(\mathrm{GE})$ are shown in Figure 1. A performance line passing through the origin of the biplot was used to determine mean performance of a genotype. The arrow on this line represents increasing mean performance. Stability line is perpendicular to this line and also passes through biplot origin (Yan, 2001). Two arrows on the opposite sides of this line represent decreased stability. The stability of genotypes for root yield in the trial was as follows: Sara $>$ Irina $>$ Lara $>$ Drena.

Site regression biplot analysis was successfully used in research for mega-environment exploration of different field crops in Serbia (Mitrovic et al. 2011; Mitrovic et al. 2012; Balalić et al. 2013). The graphic representation of multi-environment trials makes it possible to group the locations into mega-environments and to identify the best hybrid for each location (Yan et al., 2000). Genotypes that are farthest away from the origin of the coordinate system are connected by a line forming a polygon and the mega-environments are separated by lines, perpendicular to the polygon sides. In both years environments in which hybrids were tested are located in two sectors (Figure 1). In the year 2009 the NS environment was in a sector of its own and had three suitable varieties, while other environments formed one mega-environment where varieties Drena and Lara had the highest yields. During 2010 variety Drena had the highest yield in first megaenvironment, while in second mega-environment it was variety Nora.

Varieties Vera and Lara, who belong to Z- type, were the most stable for the trait of sugar content in both years (Figure 2). Seven sugar beet varieties studied in seven environments in 2009 and 2010 for sugar content formed a polygon incorporating six sectors. In the year 2009 varieties Darija and Vera had the highest sugar content in mega-environment that included locations SM, ZR, KI. Variety Lara had the best results in location PA. Varieties Vera and Lara performed best in the year 2010, in mega-environment that included all locations except SM, where variety Darija had the highest sugar content.

The best indicator of sugar beet variety commercial value is the trait of white sugar yield. For this trait variety Lara was the most stable in both years (Figure 3). In 2009 mega-environments were identical to those
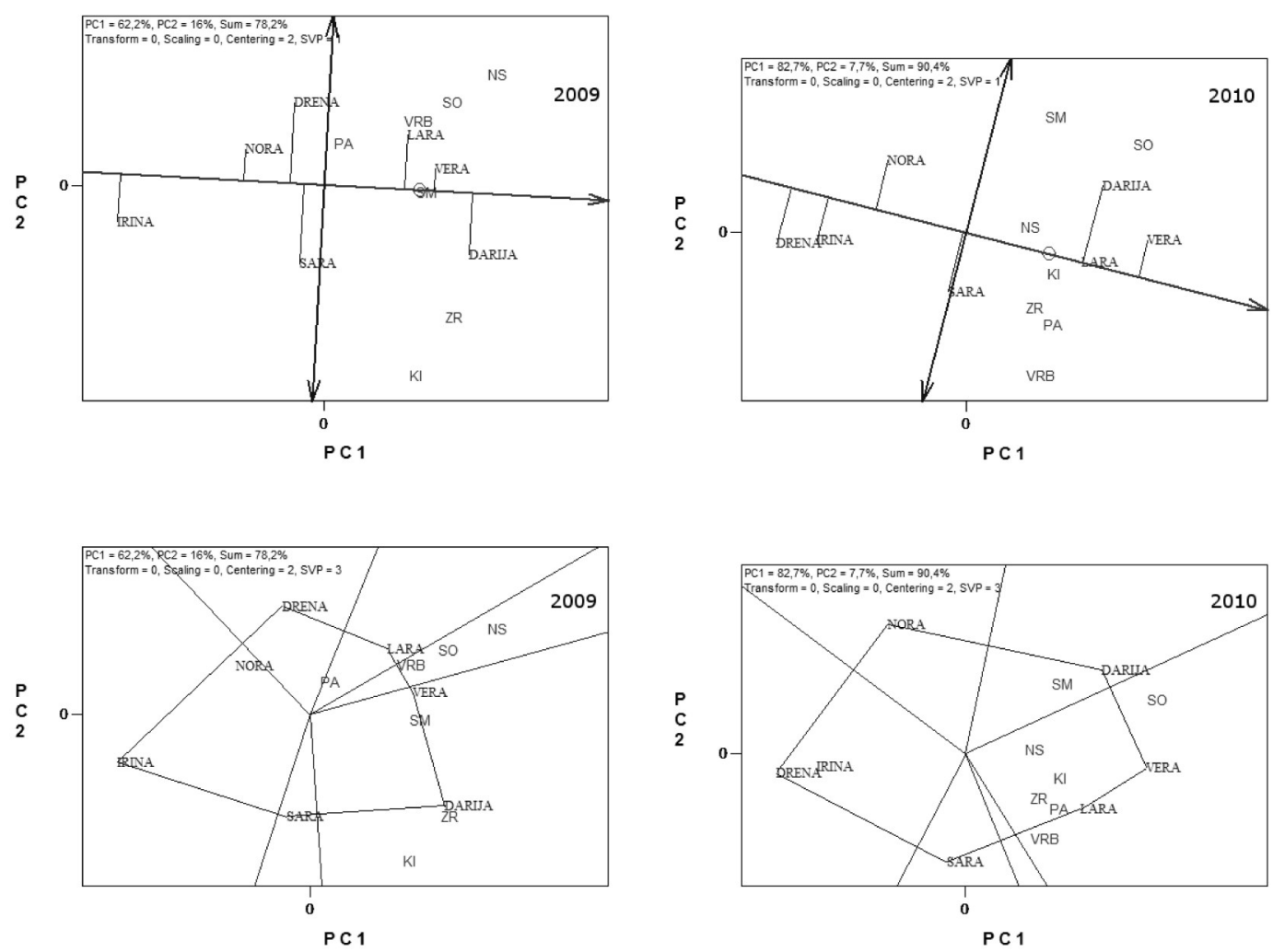

Figure 2. Mean stability and mega-environments for sugar content in 2009 and 2010 

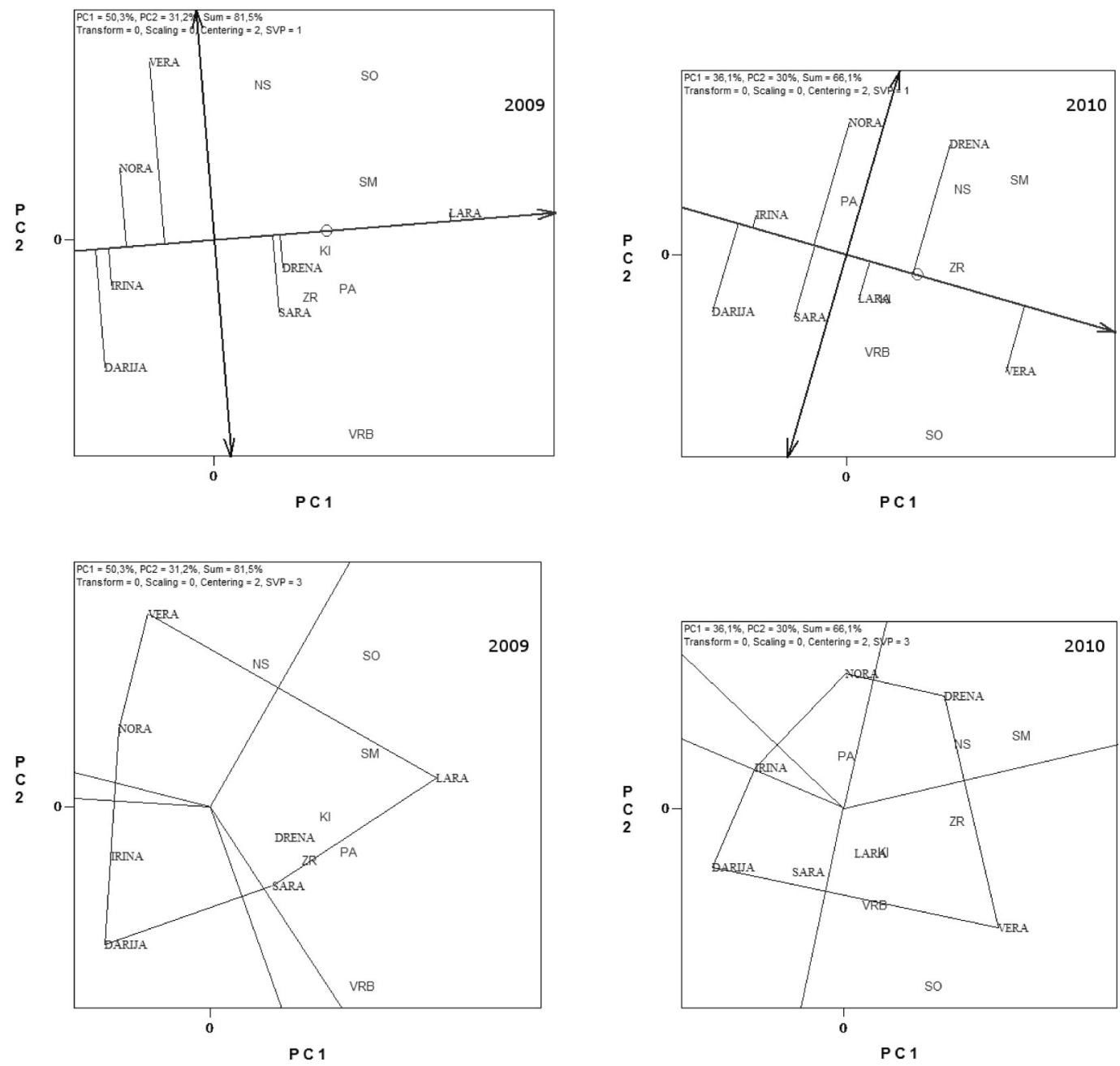

Figure 3. Mean stability and mega-environments for white sugar yield in 2009 and 2010

formed according to root yield. The NS environment was in a sector of its own and had two suitable varieties, Nora and Vera. Other environments formed one big mega-environment where varieties Lara and Drena were the highest yielding. In 2010 there were three megaenvironments. Variety Nora best performed in environment PA, while variety Drena showed best results in environments NS and SM. In the biggest mega -environment the best performance showed varieties Vera and Lara.

\section{Conclusions}

The variations of root yield, sugar content and white sugar yield are mostly caused by environment, although genotype was also a significant factor of variation. GEI did not have a significant effect on traits variation, which is probably due to the stability and adaptability of tested varieties, as well as the specific nature of sugar beet growing and exploitation.
According to the presented results, the most stable varieties for the trait of root yield were Sara and Irina, for the trait sugar content Lara and Vera and for white sugar yield variety Lara. This study identified optimal locations for particular varieties, which will be useful in determining which varieties are best suited for specific areas.

\section{References}

Ahmadi, M., Herevan, E. M., Sadeghian, S. Y, Mesbah, M., Darvish, F. (2011): Drought tolerance variability in $S_{1}$ pollinator lines developed from sugar beet open population. Euphytica, 178, 339-349. https://dx.doi.org/10.1007/s10681010-0307-8

Balalić, I., Branković, G., Zorić, M., Miklič, V., Jocić, S., ŠurlanMomirović, G. (2013): Sunflower Mega-Environments in Serbia Revealed By GGE Biplot Analysis. Ratarstvo i povrtarstvo, 50 (2), 20-27.

Bloch, D., Hoffmann, C. M. (2005): Seasonal development of genotypic differences in sugar beet (Beta vulgaris L.) and their interaction with water supply. Journal of Agronomy and Crop Science, 191, 263-272. https://dx.doi.org/10.1111/j.1439037X.2005.00150.x 
Crossa, J. (1990): Statistical analysis of multilocation trials. Advances in Agronomy, 44, 55-85. http://dx.doi.org/10.1016/S0065-2113 (08)60818-4

Čačić, N., Kovačev, L., Mezei, S., Nagl, N., Rajić, M. (2005): Adaptability and stability of NS sugar beet varieties grown in different agroecological conditions. Zbornik radova Instituta za ratarstvo i pourtarstvo, Novi Sad, 41, 135-143.

Djurić, N., Matković, M., Cvijanović, G., Dozet, G. (2016): Analysis of Main Additive Effects and Multiplicative Interactions of Components of Yield of Certain Wheat Genotypes. Ratarstvo $i$ povrtarstvo, 53, 61-68. https:// dx.doi.org/10.5937/ratpov53-9810

Gabriel, K. R. (1971): The biplot graphic display of matrices with applications to principal component analysis. Biometrics, 58, 453-467.

Gauch, H. G., Zobel, R. W. (1996): Genotype by environment interaction. CRC Press. Boca Raton, Florida, USA.

Hoffmann, C. M., Huijbregts, T., van Swaaij, N., Jansen, R. (2009): Impact of different environments in Europe on yield and quality of sugar beet genotypes. European Journal of Agronomy, 30, 17-26. https://dx.doi.org/10.1016/j.eja.2008.06.004

Kaya, Y., Akçura, M., Taner, S. (2006): GGE-biplot analysis of multienvironment yield trials in bread wheat. Turkish Journal of Agriculture and Forestry, 30, 325-337.

Kovačev, L., Čačić, N., Mezei, S., Nagl, N. (2005): Possibilities of genetics, breeding and genetic engineering in creation of rhizomania resistant sugar beet genotypes and productivity of NS sugar beet hybrid varieties. Zbornik radova Instituta za ratarstvo i povrtarstvo, Novi Sad, 41, 35-50.

Kovačev, L., Čačić, N., Mezei, S., Stojaković, Ž. (2007): Productivity of NS hybrid cultivars of sugar beet in two-year multi-location trials. A periodical of scientific research on field and vegetable crops, 43, 161-167.

Kovačev, L., Ćačić, N., Mezei, S. (2011): New sugar beet hybrid varieties developed at Institute of Field and Vegetable Crops resistant to rhizomania. Ratarstvo i pourtarstvo, 48, 83-86.

Mitrović, B., Stanisavljević, D., Treskić, S., Stojaković, M., Bekavac, G., Nastasić A., Ivanović, M. (2011): GGE Biplot Analysis of Multi-Environment Trials of NS Maize Hybrids. Ratarstvo i pourtarstvo, 48, 77-82.
Mitrović, B., Stanisavljević, D., Treskić, S., Stojaković, M., Ivanović, M., Bekavac, G., Rajković, M. (2012): Evaluation of experimental Maize hybrids tested in Multi-location trials using AMMI and GGE biplot analysis. Turkish Journal of Field Crops, 17, 35-40.

Mladenov, V., Banjac, B., Milošević, M. (2012): Evaluation of yield and seed requirements stability of bread wheat (Triticum aestivum L.) via AMMI model. Turkish Journal of Field Crops, 17, 203-207

Oliveira, R. L., von Pinho, R. G., Balestre, M., Ferreira, D. V. (2010): Evaluation of maize hybrids and environmental stratification by the methods AMMI and GGE biplot. Crop Breeding and Applied Biotechnology, 10, 247-253. http://dx.doi.org/10.1590/S1984-70332010000300010

R DEVELOPMENT CORE TEAM 2013. R: A Language and Environment for Statistical Computing. R Foundation for Statistical Computing, Vienna, Austria.

Reinefeld, E., Emmerich, A., Baumgarten, G., Winner, C.,Beiss, U. (1974): Zurvoraussage des melassezukers ausrubenanalysen. Zucker, 27, 2-15.

Satterthwaite, F. E. (1946): An approximate distribution of estimates of variance components. Biometrics Bulletin, 2, 110114. https://dx.doi.org/10.2307/3002019

Sayar, M. S., Anlarsal, A. E., Basbag, M. (2013): Genotypeenvironment interactions and stability analysis for dry-matter yield and seed yield in Hungarian vetch (Vicia pannonica Crantz.). Turkish Journal of Field Crops, 18, 238-246.

Yan, W. (2001): GGE biplot - A Windows Application for Graphical Analysis of Multienvironment Trial Data and Other Types of Two-Way Data. Agronomy Journal, 93, 1111-1118. https://dx.doi.org/10.2134/agronj2001.9351111x

Yan, W., Hunt, L. A., Sheng, Q., Szlavnics, Z. (2000): Cultivar evaluation and mega-environment investigation based on the GGE biplot. Crop Science, 40, 597-605. https:// dx.doi.org/10.2135/cropsci2000.403597x

Yan, W., Kang, M. S., Ma, B., Woods, S., Cornelius, P. L. (2007): GGE Biplot vs. AMMI analysis of genotype-by-environment data. Crop Science, 47, 643-655. https://dx.doi.org/10.2135/ cropsci2006.06.0374

\section{Analiza multilokacijskih ogleda šećerne repe primenom GGE biplot metoda}

\section{Živko Ćurčić · Dario Danojević · Bojan Mitrović . Mihajlo Ćirić · Ksenija Taški-Ajduković · Nevena Nagl}

Sažetak: Multilokacijski ogledi izvode se svake godine sa ciljem procene hibrida šećerne repe u različitim agroekološkim uslovima Srbije. Cilj ovog istraživanja je bio da se utvrdi uticaj genotipa, spoljašnje sredine, kao i interakcije genotipa i spoljašnje sredine na prinos korena, sadržaj šećera i prinos kristalnog šećera. GGE biplot metod je korišćen za procenu stabilnosti sedam hibrida šećerne repe stvorenih u Institutu za ratarstvo i povrtarstvo. Mešoviti model analize varijanse (ANOVA) je korišćen za analizu rezultata ogleda. U pretpostavci analize varijanse efekat genotipa je bio fiksan, dok su efekti godine i sredine bili slučajne promenljive. ANOVA je pokazala da je najveći efekat na prinos korena i prinos kristalnog šećerna imala spoljašnja sredina, dok je godina imala najveći uticaj na sadržaj šećera. Genotip je imao značajan uticaj na varijabilnost svih ispitivanih osobina, dok uticaj interakcije genotip/sredina nije bio značajan. Rezultati analize GGE biplota ukazuju da je Sara bila najstabilniji hibrid za prinos korena, dok su sadržaj šećera i prinos kristalnog šećera bili najstabilniji kod hibrida Lara. Identifikovane su optimalne lokacije za svaki genotip, što može biti od koristi pri davanju preporuka za gajenje hibrida šećerne repe u određenim regionima proizvodnje ovog useva.

Ključne reči: GGE biplot analiza, multilokacijski ogledi, prinos korena, prinos kristalnog šećera, sadržaj šećera, šećerna repa 